\title{
Dose-Response CuRve to Soil Applied Herbicides ANd Susceptibility Evaluation of Different Amaranthus Species USING MODEL IDENTITY ${ }^{1}$
}

\author{
Curva Dose-Resposta de Herbicidas Aplicados ao Solo e Avaliação da Susceptibilidade de \\ Diferentes Espécies de Amaranthus pela Identidade de Modelos
}

\author{
RAIMONDI, M.A. ${ }^{2}$, OLIVEIRA J-R., R.S. ${ }^{3}$, CONSTANTIN, J. ${ }^{3}$, RIOS, F.A. ${ }^{3}$, GEMELLI, A. ${ }^{3}$, and \\ RAIMONDI, R.T. ${ }^{3}$
}

\begin{abstract}
Greenhouse studies were conducted in 2008-2009 with the objective of adjusting dose-response curves of the main soil-applied herbicides currently used in cotton for the control of Amaranthus viridis, A. hybridus, A. spinosus, A. lividus, as well as comparing susceptibility among different species, using the identity test models. Thirty six individual experiments were simultaneously carried out in greenhouse, in a sandy clay loam soil (21\% clay, $2.36 \% \mathrm{OM}$ ) combining increasing doses of the herbicides alachlor, clomazone, diuron, oxyfluorfen, pendimethalin, prometryn, S-metolachlor, and trifluralin applied to each species. Dose-response curves were adjusted for visual weed control at 28 days after herbicide application and doses required for $80 \%\left(\mathrm{C}_{80}\right)$ and $95 \%\left(\mathrm{C}_{95}\right)$ control were calculated. All herbicides, except clomazone and trifluralin, provided efficient control of most Amaranthus species, but substantial differences in susceptibility to herbicides were found. In general, A. lividus was the least sensitive species, whereas A. spinosus demonstrated the highest sensitivity to herbicides. Alachlor, diuron, oxyfluorfen, pendimethalin, S-metolachlor, and prometryn are efficient alternatives to control Amaranthus spp. in a range of doses that are currently lower than those recommended to cotton.
\end{abstract}

Keywords: cotton, dose-response curve, pigweed, tolerance.

\begin{abstract}
RESUMO - Em 2008/2009 foram conduzidos estudos em casa de vegetação com o objetivo de ajustar curvas de dose-resposta dos principais herbicidas usados atualmente em pré-emergência no algodoeiro para controle de Amaranthus viridis, A. hybridus, A. spinosus e A. lividus, bem como para comparar a suscetibilidade entre espécies diferentes, utilizando o teste de identidade de modelos. Trinta e seis experimentos individuais foram realizados simultaneamente em casa de vegetação, empregando solo franco-arenoso (argila, 21\%; OM, 2,36\%), combinando doses crescentes dos herbicidas alachlor, clomazone, diuron, oxyfluorfen, pendimethalin, prometryn, S-metolachlor e trifluralin, aplicadas a cada uma das espécies. As curvas de dose-resposta foram ajustadas em relação à avaliação de controle visual das plantas daninhas aos 28 dias após a aplicação dos herbicidas, sendo calculadas doses necessárias para o controle de 80\% (C80) e 95\% (C95). Todos os herbicidas, com exceção de clomazone e trifluralin, resultaram em controle eficiente da maioria das espécies de Amaranthus, porém diferenças substanciais na suscetibilidade aos herbicidas foram encontradas. Em geral, A. lividus foi a espécie menos sensivel, ao passo que A. spinosus demonstrou a maior sensibilidade aos herbicidas. Alachlor, diuron, oxyfluorfen, pendimethalin, S-metolachlor e prometryn são alternativas eficientes para controle de Amaranthus spp. em uma faixa de doses que se encontram inferiores às recomendadas atualmente para o algodão.
\end{abstract}

Palavras-chave: algodão, curva de dose-resposta, caruru, tolerância.

1 Recebido para publicação em 9.12.13 e aprovado em 16.7.2014.

2 Agro MR Defensivos Agrícolas Ltda, Francisco Alves-PR, Brasil, <michelraimondi@hotmail.com>; ${ }^{3}$ Universidade Estadual de Maringá, Maringá-PR, Brasil. 


\section{INTRODUCTION}

Despite the recent developments in cotton production, one of the most important problems still faced by farmers from sowing to harvest is the interference provided by weeds. Weeds compete with the crop for nutrients, water, light, and space, and cause damage to cotton fiber during harvest and processing. Reported losses in fiber yield can reach $81-90 \%$ after the coexistence of cotton and weeds throughout the whole crop cycle (Fast et al., 2009).

A significant weed problem in Brazil is Amaranthus. At early seedling stages, farmers usually have problems to identify and differentiate Amaranthus species, so they are usually referred as pigweeds. In the main areas of cotton production in Brazil (Mato Grosso and Bahia), there is a marked increase in the number of reports on insufficient pigweed control. Amaranthus species are characterized as aggressive and highly competitive, in addition to having the potential to cause damages to cotton fiber, besides the problems related to resistance to herbicides (Sosnoskie et al., 2011; Bell et al., 2013).

Currently, cottonweed is almost exclusively managed with the use of herbicides, through applications in pre or post-emergence of weeds and/or crops. Due to the particular requirements of cotton, it is usually necessary to have herbicides applied 2-5 times per crop cycle. Pre-emergence herbicides remain popular among cotton growers, because they prevent early weed interference. They also provide a more flexible timing for postemergence applications (Whitaker et al., 2011). Despite the broad use of pre-emergence herbicides, doses actually applied are usually lower than the recommended, due to the marginal selectivity of some herbicides to cotton. The effects of sub doses on effective weed control are still unclear.

Information concerning the best combination of herbicide/dose is of considerable importance to weed control and selectivity to crop. Several authors have used dose-response curves to study the biological effect of herbicides for various aspects, including weed control and/or resistance of weeds, herbicide persistence in soil, as well as to verify the differential susceptibility among species belonging to the same genus (Steckel \& Gwathmey, 2009). This work focused on establishing doses of preemergence herbicides capable of promoting adequate control of four species of Amaranthus. A secondary objective was to compare the differential susceptibility of four Amaranthus species to various herbicides using identity test models.

\section{MATERIAL AND METHODS}

Experiments were conducted under greenhouse conditions from October 2008 to March 2009. Seeds of Amaranthus hybridus, A. spinosus, A. lividus and A. viridis, which had no previous reports of resistance to herbicides, were provided by Agro Cosmos Ltda. (Engenheiro Coelho - SP, Brazil).

Experimental units were made up of pots with capacity of $4 \mathrm{dm}^{-3}$ of soil. The pots were filled with a sandy clay loam soil, with $21 \%$ clay, $71 \%$ sand, $2.36 \%$ organic matter and $\mathrm{pH}_{\mathrm{H} 2 \mathrm{O}}=5.2$. One hundred seeds were placed per pot at $1-1.5 \mathrm{~cm}$ depth, and each experimental unit contained only one weed species.

Treatments consisted of nine herbicides applied pre-emergence at three or four doses, depending on the herbicide, and a no herbicide control. Herbicides and doses applied were as follows: alachlor (240; 480; 720; $\left.1,440 \mathrm{~g} \mathrm{ha}^{-1}\right)$; clomazone (125; 250; 500; 1,000 $\left.\mathrm{g}^{-1} \mathrm{~h}^{-1}\right)$; diuron (63; 125; 250; $\left.500 \mathrm{~g} \mathrm{ha}^{-1}\right)$; oxyfluorfen $(12 ; 24$; 48; $\left.96 \mathrm{~g} \mathrm{ha}^{-1}\right)$; pendimethalin $(94 ; 188 ; 375$; $\left.750 \mathrm{~g} \mathrm{ha}^{-1}\right)$; prometryn $(125 ; 250 ; 500$; $\left.750 \mathrm{~g} \mathrm{ha}^{-1}\right)$; S-metolachlor $(90 ; 180 ; 360$; $\left.720 \mathrm{~g} \mathrm{ha}^{-1}\right)$; trifluralin $450\left(113 ; 225 ; 450 \mathrm{~g} \mathrm{ha}^{-1}\right)$ and trifluralin $600\left(150 ; 300 ; 600 \mathrm{~g} \mathrm{ha}^{-1}\right)$. Each herbicide-weed combination was carried out as an isolated experiment, totaling 36 experiments conducted simultaneously. In each experiment, treatments were organized in a randomized blocks design with four replicates.

After sowing, pots were irrigated and herbicides were applied 24 hours thereafter. Herbicide applications were accomplished using a backpack sprayer equipped with XR110.02 flat fan nozzles calibrated to deliver a spray volume of $200 \mathrm{~L} \mathrm{ha}^{-1}$ at a pressure of $2.5 \mathrm{~kg} \mathrm{~cm}^{-2}$. Following application, pots were 
irrigated to provide enough water supply for plant growth. Environmental conditions during applications included air temperature between 24 and $26{ }^{\circ} \mathrm{C}$ and relative humidity between 80 and $89 \%$. After applying the experimental units were watered as necessary.

Weed control was rated 28 days after herbicide application (DAT). Ratings were based on visual scale 0 to $100 \%$, where 0 stands for no visible plant injury and 100 means complete weed control. Data were submitted to analysis of variance and regression, and were fit to the logistic nonlinear regression model proposed by Streibig (1988):

$$
y=\frac{a}{\left[1+\left(\frac{x}{b}\right)^{c}\right]}
$$

where $y=\%$ weed control; $x=$ herbicide dose (g ha ${ }^{-1}$ ), and $a, b$ and $c=$ equation estimated parameters, in which: $a=$ amplitude between the minimum and maximum $y$ points; $b=$ dose that provides $50 \%$ of variable response; $c=$ curve slope around $b$.

Data were fit to the linear regression model for both trifluralin formulations and to the quadratic model for clomazone.

Using the adjusted equations, doses of herbicides that provide $80 \%\left(\mathrm{C}_{80}\right)$ ("minimum acceptable level of weed control") and 95\% control $\left(\mathrm{C}_{95}\right)$ ("excellent weed control"), for each species was calculated. $\mathrm{C}_{80}$ and $\mathrm{C}_{95}$ values were also used to compare susceptibility among Amaranthus species to herbicides.

As reported, was used nonlinear logistic Streibig (1988) model to express the control of each Amaranthus species, relative to rate of each one of the herbicides evaluated. Thus, a model was adjusted for each species (four species) and herbicides. However, to validate the confirmation and the comparison of differential susceptibility between the four Amaranthus species within each herbicide, and their respective controls, you are supposed to test the hypotheses referent to model identity regarding the species, as method described by Regazzi (1999, 2003) and Regazzi \& Silva (2004, 2010). This procedure was used to prove statistically if there are differences between the curves of individually species adjusted or if there is the possibility of using a standard model to all species related to the control provided for each herbicide. The nonlinear identity model test was submitted to alachlor, diuron, oxyfluorfen, pendimethalin, S-metolachlor and prometryne herbicides, which were adjusted to the logistic model described by Streibig (1988).

The first step in this stage was adding an indicator variable (dummy) to chosen model, whose goal is to represent each one of the four weed species under study. Such a model, termed as complete, in the other words, with all four regression is the following:

$$
\begin{aligned}
\mathrm{Y} & =D_{1}\left\{\mathrm{~A}_{1} /\left[1+\left(\mathrm{X} / \mathrm{B}_{1}\right)^{\mathrm{C}}{ }_{1}\right]\right\}+\mathrm{D}_{2}\left\{\mathrm{~A}_{2} /\left[1+\left(\mathrm{X} / \mathrm{B}_{2}\right)^{\mathrm{C}}{ }_{2}\right]\right\} \\
& +\mathrm{D}_{3}\left\{\mathrm{~A}_{3} /\left[1+\left(\mathrm{X} / \mathrm{B}_{3}\right)^{\mathrm{C}}{ }_{3}\right]\right\}+\mathrm{D}_{4}\left\{\mathrm{~A}_{4} /\left[1+\left(\mathrm{X} / \mathrm{B}_{4}\right)_{4}^{\mathrm{C}}\right]\right\}+\varepsilon_{i}
\end{aligned}
$$

where $i=1, \ldots, 4$, are the variables dummy $D_{i}$ such that: $D_{i}=1$ if the observation Y belongs to the group 1; 0 otherwise; $\mathrm{A}_{i}, \mathrm{~B}_{i}$ e $\mathrm{C}_{i}$ are the model's parameters to each one of the four Amaranthus species, where $i=1,2,3$ e 4; $\varepsilon_{i}$ is the aleatoric error term, $\varepsilon_{i} \sim N\left(0, \sigma^{2}\right)$.

For the nonlinear regression models the hypotheses evaluated to each herbicides were:

$$
\begin{aligned}
& \text { - HO: } \mathrm{A}_{1}=\mathrm{A}_{2}=\mathrm{A}_{3}=\mathrm{A}_{4}=\mathrm{A}, \mathrm{B}_{1}=\mathrm{B}_{2}=\mathrm{B}_{3}=\mathrm{B}_{4}=\mathrm{B}, \\
& \mathrm{C}_{1}=\mathrm{C}_{2}=\mathrm{C}_{3}=\mathrm{C}_{4}=\mathrm{C}
\end{aligned}
$$

- Ha: at least an equality is an inequality.

To compare nonlinear regression models and consequently the hypotheses test, Bates \& Watts (1988) showed a based test on likelihood ratio, with approximation given for $\mathrm{F}$ statistic.

Therefore, initially was realized a nonlinear regression analysis to the four species with herbicides. From this analysis all parameters were determined to the complete model. For these analyses the procedures used were PROC GLM and NLIN (SAS, 1999).

\section{RESULTS AND DISCUSSION}

The test result with approximation given for F statistics (Bates \& Watts, 1988), which identifies the identity of regression models, to the hypotheses about parameter equality is showed on Table 1. 
Table 1 - Calculated F $\left(\mathrm{F}_{\text {cal }}\right)$, Freedom Degrees (F.D) and H0 hypotheses results by F statistic

\begin{tabular}{|l|c|c|c|c|}
\hline \multicolumn{1}{|c|}{ Herbicide } & Hypotheses & Fcal & F.D. & P(F $>$ Fcal $)$ \\
\hline Alachlor & $\mathrm{H} 0: \mathrm{A}_{1}=\mathrm{A}_{2}=\mathrm{A}_{3}=\mathrm{A}_{4}=\mathrm{A}, \mathrm{B}_{1}=\mathrm{B}_{2}=\mathrm{B}_{3}=\mathrm{B}_{4}=\mathrm{B}, \mathrm{C}_{1}=\mathrm{C}_{2}=\mathrm{C}_{3}=\mathrm{C}_{4}=\mathrm{C}$ & 42,50 & 12.52 & $<0.0001$ \\
\hline Diuron & $\mathrm{H} 0: \mathrm{A}_{1}=\mathrm{A}_{2}=\mathrm{A}_{3}=\mathrm{A}_{4}=\mathrm{A}, \mathrm{B}_{1}=\mathrm{B}_{2}=\mathrm{B}_{3}=\mathrm{B}_{4}=\mathrm{B}, \mathrm{C}_{1}=\mathrm{C}_{2}=\mathrm{C}_{3}=\mathrm{C}_{4}=\mathrm{C}$ & 1.2496 & 12.52 & $<0.3017$ \\
\hline Oxyfluorfen & $\mathrm{H} 0: \mathrm{A}_{1}=\mathrm{A}_{2}=\mathrm{A}_{3}=\mathrm{A}_{4}=\mathrm{A}, \mathrm{B}_{1}=\mathrm{B}_{2}=\mathrm{B}_{3}=\mathrm{B}_{4}=\mathrm{B}, \mathrm{C}_{1}=\mathrm{C}_{2}=\mathrm{C}_{3}=\mathrm{C}_{4}=\mathrm{C}$ & 68.31 & 12.52 & $<0.0001$ \\
\hline Pendimethalin & $\mathrm{H} 0: \mathrm{A}_{1}=\mathrm{A}_{2}=\mathrm{A}_{3}=\mathrm{A}_{4}=\mathrm{A}, \mathrm{B}_{1}=\mathrm{B}_{2}=\mathrm{B}_{3}=\mathrm{B}_{4}=\mathrm{B}, \mathrm{C}_{1}=\mathrm{C}_{2}=\mathrm{C}_{3}=\mathrm{C}_{4}=\mathrm{C}$ & 15.25 & 12.52 & $<0.0001$ \\
\hline S-Metolachlor & $\mathrm{H} 0: \mathrm{A}_{1}=\mathrm{A}_{2}=\mathrm{A}_{3}=\mathrm{A}_{4}=\mathrm{A}, \mathrm{B}_{1}=\mathrm{B}_{2}=\mathrm{B}_{3}=\mathrm{B}_{4}=\mathrm{B}, \mathrm{C}_{1}=\mathrm{C}_{2}=\mathrm{C}_{3}=\mathrm{C}_{4}=\mathrm{C}$ & 11.86 & 12.52 & $<0.0001$ \\
\hline Prometryne & $\mathrm{H} 0: \mathrm{A}_{1}=\mathrm{A}_{2}=\mathrm{A}_{3}=\mathrm{A}_{4}=\mathrm{A}, \mathrm{B}_{1}=\mathrm{B}_{2}=\mathrm{B}_{3}=\mathrm{B}_{4}=\mathrm{B}, \mathrm{C}_{1}=\mathrm{C}_{2}=\mathrm{C}_{3}=\mathrm{C}_{4}=\mathrm{C}$ & 17.19 & 12.52 & $<0.0001$ \\
\hline
\end{tabular}

The HO hypotheses were rejected to all herbicides, but diuron. Thus, each species tested differ significantly in at least one of the other species. As the HO test was significant, but diuron, it can be concluded that it is not possible to use a single logistic regression model to represent the different Amaranthus species control. Thus, the Amaranthus susceptibility species evaluated differ significantly of each other among each herbicide, but diuron. Therefore, the results show that just for diuron is possible to use one equation to represent all species control, assuming equality between them to this herbicide action. For the other herbicides in evaluation, interpretations and discussions related to the models should be made to each Amaranthus species and their respective control levels.

Dose-response curves adjusted to alachlor, diuron, oxyfluorfen, pendimethalin, S-metolachlor and prometryn are presented in Figure 1. Parameters $a, b$ and $c$ of the logistic model as well as determination coefficients $\left(\mathrm{R}^{2}\right), \mathrm{C}_{80}$ and $\mathrm{C}_{95}$ values are described in Table 2 .

$\mathrm{C}_{80}$ values for alachlor ranged from 292 to $804 \mathrm{~g} \mathrm{ha}^{-1}$ among different species, with $A$. spinosus the most susceptible species, and A. lividus the least susceptible species. A. hybridus required the highest herbicide dose $\left(1,154 \mathrm{~g} \mathrm{ha}^{-1}\right)$, and $A$. spinosus the lowest dose $\left(596 \mathrm{~g} \mathrm{ha}^{-1}\right)$ to reach $95 \%$ control $\left(\mathrm{C}_{95}\right)$ (Table 2). Alachlor is considered as a highly soluble, low sorbed herbicide, and its sorption depends mainly on soil OM and, to a lesser extent, clay contents in soil (Oliveira Jr. et al., 2001). Hence, when applied to a soil with low contents of OM and clay, doses lower than the recommended could result in good initial control of weeds.
By accepting the hypothesis $\mathrm{HO}$ in identity testing models, it is assumed that there is no difference between the species and the possibility of using a common model (full model) for all species compared to the control provided by diuron. By adjusting complete model for the species, it was determined that $221 \mathrm{~g} \mathrm{ha}^{-1}$ and $284 \mathrm{~g} \mathrm{ha}^{-1}$ required the highest doses both for $80 \%$ control $\left(221 \mathrm{~g} \mathrm{ha}^{-1}\right)$ and for $95 \%$ weed control (284 $\left.\mathrm{g} \mathrm{ha}^{-1}\right)$ (Table 2). In a greenhouse to soil texture sandy clay loam ( $21 \%$ clay and $13.68 \mathrm{~g} \mathrm{dm}^{-3}$ carbon), Raimondi et al. (2010) verified that $260 \mathrm{~g} \mathrm{ha}^{-1}$ of soil-applied diuron promoted $100 \%$ control of A. lividus, $A$. hybridus, $A$. spinosus e $A$. viridis up to 30 days after application (DAA). Cruz \& Toledo (1982) observed that diuron at $1,000 \mathrm{~g} \mathrm{ha}^{-1}$ used pre-emergence in cotton provided $96.5 \%$ reduction of weed infestation until 31 DAA in a sandy clay soil. Although greenhouse studies focus mainly in a specific flush of weeds and field experiments are designed to evaluate herbicide effect on sequential fluxes, previous resulted found in literature have shown that diuron is efficient to control these species, but in higher doses than those found in the present work. Differences in doses required under field conditions are usually correlated to soil properties, i.e. soils with higher contents of $\mathrm{OM}$ and clay present higher herbicide retention capacity, reducing the availability to plants, which implies in the need of using higher doses (Inoue et al., 2006, 2009).

Oxyfluorfen $\mathrm{C}_{80}$ and $\mathrm{C}_{95}$ doses ranged from 30 to $76 \mathrm{~g} \mathrm{ha}^{-1}$ and 43 to $87 \mathrm{~g} \mathrm{ha}^{-1}$ respectively among species (Table 2). A. lividus was the least sensitive species, which was similar to what was observed for alachlor and diuron. A. spinosus and A. hybridus were the most susceptible species. 

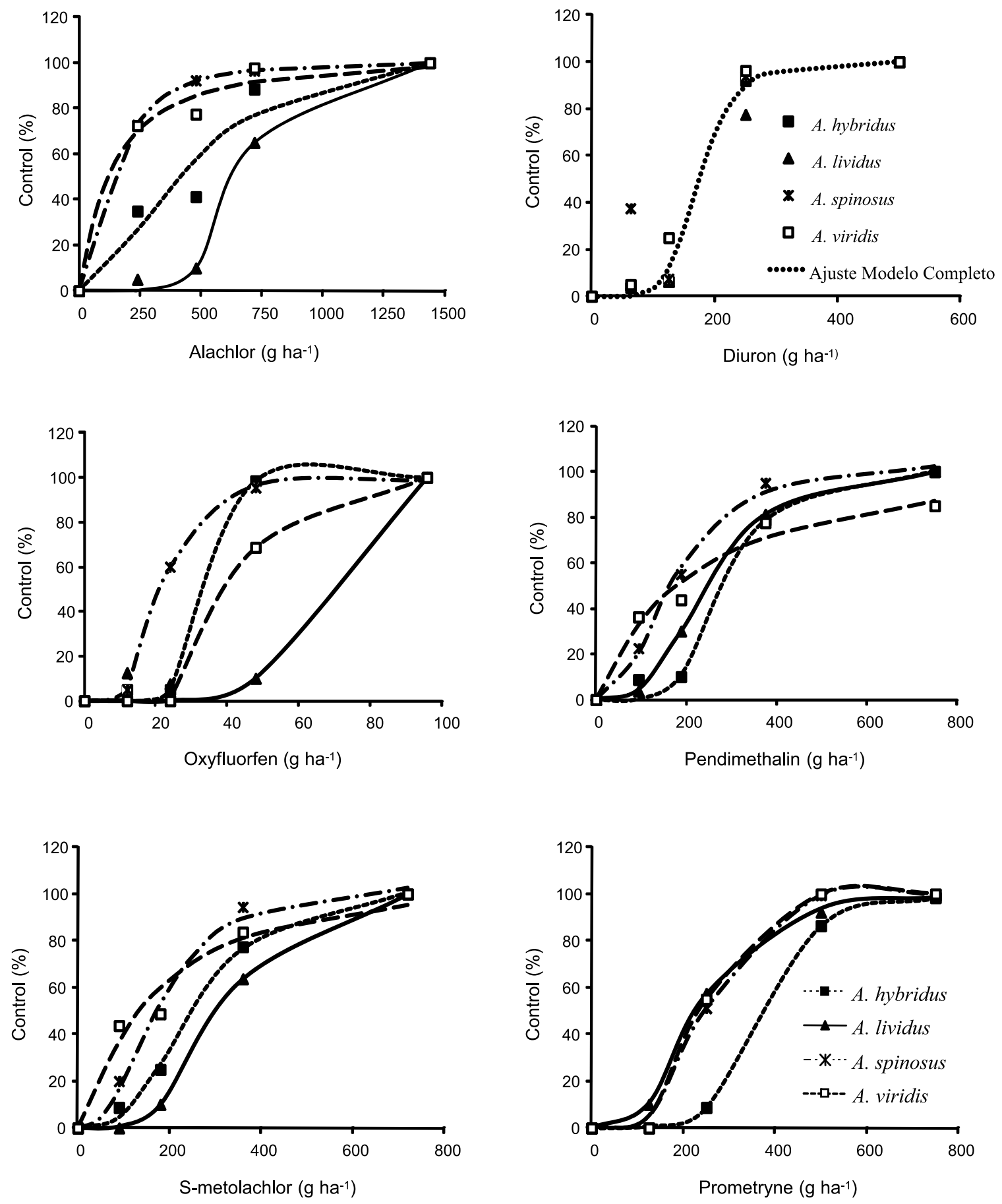

Figure 1 - Dose-response curves of alachlor, diuron, oxyfluorfen, pendimethalin, S-metolachlor and prometryn for A. hybridus, A. lividus, A. viridis and A. spinosus, \% control (28 DAT).

In contrast to what was observed for the previous herbicides, A. viridis was the species that had the least susceptibility to pendimethalin $\left(\mathrm{C}_{80}=537 \mathrm{~g} \mathrm{ha}^{-1} ; \mathrm{C}_{95}>\right.$ $750 \mathrm{~g} \mathrm{ha}^{-1}$ ) (Table 2). The most sensitive species was $A$. spinosus as previously observed for other herbicides. Excellent control of A. rudis (92\%) with pendimethalin (920 $\left.\mathrm{g} \mathrm{ha}^{-1}\right)$ was reported by Sweat et al. (1998), whereas they did not observe acceptable levels of 
Table 2 - Estimates of parameters $a, b$ and $c$, determination coefficients $\left(\mathrm{R}^{2}\right)$ of the logistic model in relation to \% control $28 \mathrm{DAT}$ and estimated doses for $80\left(\mathrm{C}_{80}\right)$ or $95 \%\left(\mathrm{C}_{95}\right)$ control

\begin{tabular}{|c|c|c|c|c|c|c|}
\hline \multirow[b]{2}{*}{ Herbicide } & \multicolumn{6}{|c|}{ A. hybridus } \\
\hline & $\mathrm{a}^{\underline{2} /}$ & $\mathrm{b}^{-3 /}$ & $c^{4 /}$ & $\mathrm{R}^{2}$ & $\begin{array}{c}\mathrm{C}_{80} \\
\left(\mathrm{~g} \mathrm{ha}^{-1}\right)\end{array}$ & $\begin{array}{c}\mathrm{C}_{95} \\
\left(\mathrm{~g} \mathrm{ha}^{-1}\right)\end{array}$ \\
\hline Alachlor & 115.2 & 481.0 & -1.73 & 0.93 & 774 & 1154 \\
\hline Diuron & 100.4 & 175.4 & -5.96 & 0.99 & 221 & 284 \\
\hline Oxyfluorfen & 100.0 & 31.98 & -10.26 & 0.99 & 37 & 43 \\
\hline Pendimethalin & 101.1 & 290.6 & -4.90 & 0.99 & 382 & 510 \\
\hline S-Metolachlor & 105.5 & 259.1 & -2.93 & 0.99 & 383 & 549 \\
\hline \multirow[t]{2}{*}{ Prometryn } & 99.78 & 367.4 & -6.08 & 0.99 & 463 & 601 \\
\hline & \multicolumn{6}{|c|}{ A. lividus } \\
\hline Alachlor & 100.5 & 659.6 & -6.88 & 0.99 & 804 & 999 \\
\hline Diuron & 100.4 & 175.4 & -5.96 & 0.99 & 221 & 284 \\
\hline Oxyfluorfen & 104.6 & 64.3 & -7.64 & 0.98 & 76 & 87 \\
\hline Pendimethalin & 102.7 & 247.8 & -3.24 & 0.99 & 366 & 539 \\
\hline S-metolachlor & 104.2 & 320.4 & -3.91 & 0.99 & 435 & 582 \\
\hline \multirow[t]{2}{*}{ Prometryn } & 99.98 & 230.5 & -3.49 & 0.99 & 344 & 538 \\
\hline & \multicolumn{6}{|c|}{ A. viridis } \\
\hline Alachlor & 104.6 & 128.9 & -1.15 & 0.98 & 360 & 946 \\
\hline Diuron & 100.4 & 175.4 & -5.96 & 0.99 & 221 & 284 \\
\hline Oxyfluorfen & 100.3 & 43.26 & -7.46 & 0.99 & 52 & 64 \\
\hline Pendimethalin & 110.8 & 216.0 & -1.05 & 0.98 & 537 & $>750^{\frac{1}{\prime}}$ \\
\hline S-metolachlor & 108.6 & 154.1 & -1.26 & 0.97 & 354 & 720 \\
\hline \multirow[t]{2}{*}{ Prometryn } & 100.1 & 244.2 & -8.49 & 0.99 & 288 & 345 \\
\hline & \multicolumn{6}{|c|}{ A. spinosus } \\
\hline Alachlor & 100.9 & 149.5 & -2.00 & 0.99 & 292 & 596 \\
\hline Diuron & 100.4 & 175.4 & -5.96 & 0.99 & 221 & 284 \\
\hline Oxyfluorfen & 99.09 & 21.95 & -4.70 & 0.99 & 30 & 43 \\
\hline Pendimethalin & 105.5 & 172.5 & -2.36 & 0.99 & 280 & 439 \\
\hline S-metolachlor & 106.2 & 180.6 & -2.44 & 0.99 & 286 & 433 \\
\hline Prometryn & 99.98 & 248.5 & -8.55 & 0.99 & 293 & 352 \\
\hline
\end{tabular}

${ }^{1 /}$ Exceed the range of doses in this study; ${ }^{2 /} a=$ amplitude between the minimum and maximum $y$ points; ${ }^{3 /} b=$ dose that provides $50 \%$ of variable response; ${ }^{4 /} \mathrm{c}=$ curve slope around $\mathrm{b}$.

control of $A$. retroflexus $(79 \%)$ under the same field conditions. Steckel et al. (2002) reported $93 \%$ control of Amaranthus rudis with pendimethalin applied at $930 \mathrm{~g} \mathrm{ha}^{-1}$ up to 28 DAA in a silt clay loam soil $(1.4 \% \mathrm{OM})$. Richardson et al. (2007) observed 96\% control of Amaranthus hybridus with pendimethalin at $690 \mathrm{~g} \mathrm{ha}^{-1}$ until 56 DAA in a sandy loam soil ( $1 \%$ OM). Field work carried out by Burke $\&$ Wilcut (2004) do not corroborate these results since they did not have satisfactory control of Amaranthus palmeri and Amaranthus hybridus at 28 DAT by using $840 \mathrm{~g} \mathrm{ha}^{-1}$ of pendimethalin in pre-emergence in a sandy loam soil $(2 \% \mathrm{OM})$. Although it is expected that there are differences among Amaranthus species for susceptibility to pendimethalin, other factors related to chemical and physical composition of soil, climate and weed density could significantly impact field results. Moreover, elaborating recommendations of herbicide doses based on the susceptibility of each species may be an important step in developing best-suited recommendations.

$\mathrm{OM}$ and clay content are important components of soil sorption capacity, which is the key factor controlling availability for soilapplied herbicide transport and absorption by plants. For highly sorbed, non-ionizable 
herbicides such as pendimethalin, high soil $\mathrm{OM}$ and clay contents reduce herbicide availability in soil solution (Lu et al., 2006; Sharma \& Singh, 2007) leading to the need of higher doses to ensure adequate control.

For S-metolachlor, the decreasing order of $\mathrm{C}_{80}$ values was $A$. lividus (435 $\mathrm{g} \mathrm{ha}^{-1}$ ) $>$ A. hybridus $\left(383 \mathrm{~g} \mathrm{ha}^{-1}\right)>A$. viridis $\left(354 \mathrm{~g} \mathrm{ha}^{-1}\right)$ $>$ A. spinosus (286 $\mathrm{g} \mathrm{ha}^{-1}$ ) (Table 2). A. lividus was once again the most difficult species to control as it was also observed for alachlor, diuron and oxyfluorfen. According to $\mathrm{C}_{80}$ and $\mathrm{C}_{95}$ values, $A$. spinosus was found to be the species with highest susceptibility. Field studies conducted in a silt clay loam soil with $1.4 \%$ OM demonstrate $95 \%$ control of $A$. rudis by the use of $940 \mathrm{~g} \mathrm{ha}^{-1}$ (Steckel et al., 2002), which is two to three times higher the range of effective doses found here.

A. hybridus presented the lowest sensibility to prometryn $\left(\mathrm{C}_{80}=463 \mathrm{~g} \mathrm{ha}^{-1}\right)$ followed by A. lividus (344 $\left.\mathrm{g} \mathrm{ha}^{-1}\right)$, A. spinosus (293 $\mathrm{g} \mathrm{ha}^{-1}$ ) and $A$. viridis (288 $\mathrm{g} \mathrm{ha}^{-1}$ ) (Table 2). The same trend was found for $\mathrm{C}_{95}$ doses: $A$. hybridus was the least sensitive $\left(\mathrm{C}_{95}=601 \mathrm{~g} \mathrm{ha}^{-1}\right)$ and A. viridis $\left(345 \mathrm{~g} \mathrm{ha}^{-1}\right)$ the most sensitive. Results for prometryn both for $\mathrm{C}_{80}$ and $\mathrm{C}_{95}$, were similar to those found for diuron, a fact that may be related to their similar mechanism of action (Photosystem II Inhibitors).

Within the range of applied doses (up to $1,000 \mathrm{~g} \mathrm{ha}^{-1}$ ), clomazone did not provide the minimum acceptable level of weed control $\left(\mathrm{C}_{80}\right)$ for $A$. hybridus and A. lividus (Figure 2, Table 3). $A$. spinosus and $A$. viridis were the most sensitive among the four species with $\mathrm{C}_{80}=829$ and $928 \mathrm{~g} \mathrm{ha}^{-1}$, respectively. Within the range of doses in this study, it was not possible to establish $\mathrm{C}_{95}$ values for any species of Amaranthus. Troxler et al. (2002) evaluated clomazone in pre-emergence (sandy-loam soil, 1\% OM) and found doses of $840 \mathrm{~g} \mathrm{ha}^{-1}$ to be not effective to control A. palmeri at 90 DAA. Raimondi et al. (2010) observed little residual activity in the control of Amaranthus species, with $1,000 \mathrm{~g} \mathrm{ha}^{-1}$ clomazone (in the greenhouse to soil texture sandy clay loam $21 \%$ clay and $13.68 \mathrm{~g} \mathrm{dm}^{-3}$ carbon). According to the authors, A. viridis showed the highest efficiency. For trifluralin 600 and trifluralin 450 , the range of doses used for both formulations was not sufficient to provide acceptable control of Amaranthus species (Figure 3). Maximum control obtained was around $45 \%$ for $A$. viridis provided by trifluralin 600. Similar to results found here.

Regarding the evaluated herbicides, oxyfluorfen provided efficient control of Amaranthus species at much lower doses than those recommended and/or labeled doses of

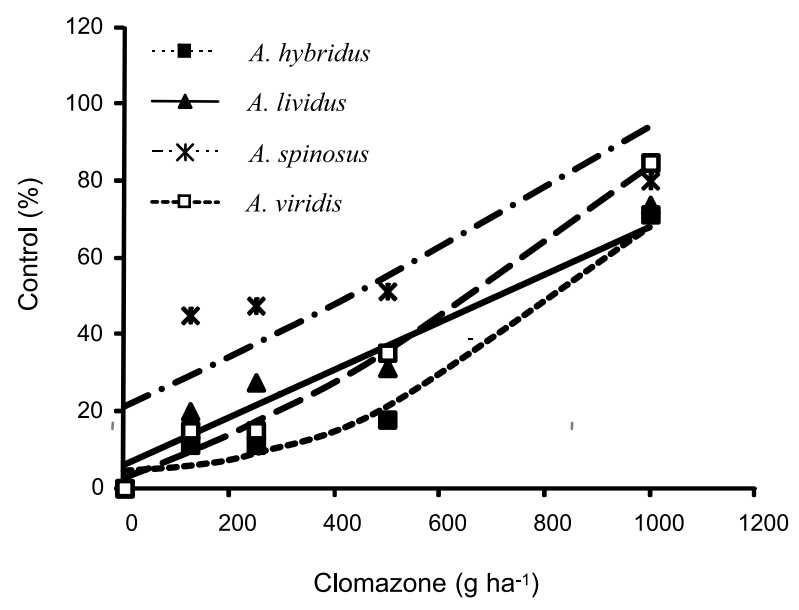

Figure 2 - Dose-response curves of clomazone for A. hybridus, A. lividus, A. viridis and A. spinosus, \% control (28 DAT).

Table 3 - Adjusted regression equations, determination coefficient $\left(\mathrm{R}^{2}\right)$, and clomazone doses for $80 \%\left(\mathrm{C}_{80}\right)$ or $95 \%\left(\mathrm{C}_{95}\right)$ of weed control in relation to percentage of visual control at 28 DAT

\begin{tabular}{|c|c|c|c|c|}
\hline Specie & $\begin{array}{c}\text { Model } \\
\% \text { Control }=\mathrm{a}_{0}+\left(\mathrm{a}_{1} * \text { dose }\right)+\left(\mathrm{a}_{2} * \operatorname{dose}^{2}\right)\end{array}$ & $\mathrm{R}^{2}$ & $\begin{array}{c}\mathrm{C}_{80} \\
\left(\mathrm{~g} \mathrm{ha}^{-1}\right) \\
\end{array}$ & $\begin{array}{c}\mathrm{C}_{95} \\
\left(\mathrm{~g} \mathrm{ha}^{-1}\right) \\
\end{array}$ \\
\hline A. hybridus & $4.39+\left(3.2610^{-3} * \mathrm{D}\right)+\left(610^{-5} * \mathrm{D}^{2}\right)$ & 0.98 & $>1000^{\frac{1 /}{1}}$ & $>1000^{1 /}$ \\
\hline A. lividus & $6.11+\left(6.1910^{-2} * \mathrm{D}\right)+\left(10^{-7} * \mathrm{D}^{2}\right)$ & 0.95 & $>1000^{1 /}$ & $>1000^{1 /}$ \\
\hline A. spinosus & $21.23+\left(6.2710^{-2} * \mathrm{D}\right)+\left(10^{-5 *} \mathrm{D}^{2}\right)$ & 0.75 & 829 & $>1000^{\frac{1 /}{}}$ \\
\hline A. viridis & $2.70+\left(5.0910^{-2} * \mathrm{D}\right)+\left(310^{-5} * \mathrm{D}^{2}\right)$ & 0.99 & 968 & $>1000^{1 /}$ \\
\hline
\end{tabular}

1 'Exceed the range of doses in this study. 

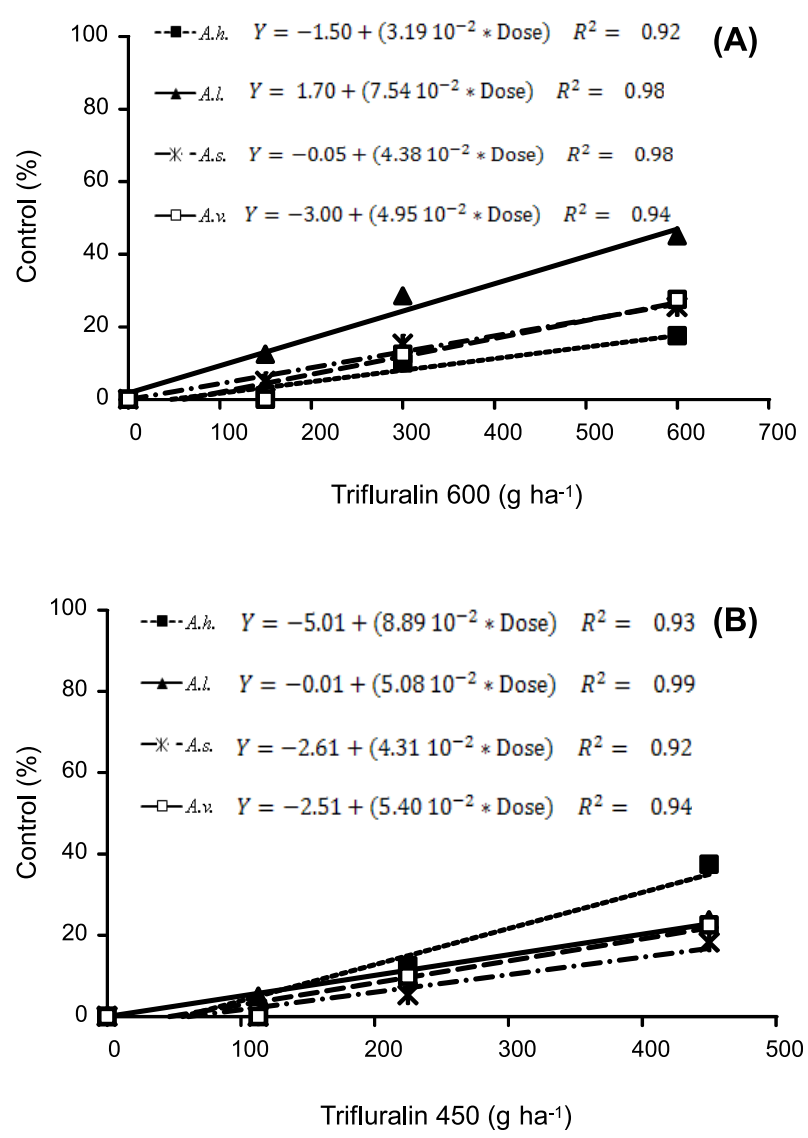

Figure 3 - Dose-response curves of trifluralin 600 (A) and trifluralin 450 (B) for A. hybridus (A.h.), A. lividus (A.l.), A. viridis (A.v.) and A. spinosus (A.s.), \% control (28 DAT).

these herbicides (Table 4). The comparisons of $\mathrm{C}_{80}$ and $\mathrm{C}_{95}$ values among species, and to the labeled doses, (Table 4) provide evidence for differential susceptibility among Amaranthus species to herbicides in this study, and provide information for a more precise choice of herbicides to be applied. In pre-emergence applications in cotton, there will probably be greater concern about A. hybridus and A. lividus, since they are the least impacted by the main herbicides used in this crop. Results demonstrate that doses considered as efficient $\left(\mathrm{C}_{80}\right.$ and $\left.\mathrm{C}_{95}\right)$ (Table 4) are inferior to those traditionally recommended and considered selective to cotton cultivated in similar soils. Another approach to cover the wide occurrence of different species under field conditions would be the combination of these herbicides to widen weed spectrum, what should be addressed in future studies. Weed satisfactory control can be obtained with the use of lower doses than those usually recommended in product labels, since such doses are fixed to reach an efficient level of control on a wide variety of weed infestation, soil, environmental and management conditions (Boström \& Fogelfors, 2002). Matching adequate herbicide doses according to soil type could be an important factor to provide more suitable recommendations.

For species of the same genre, physiological, anatomic, and biochemical factors might contribute to a peculiar susceptibility to herbicides. Characteristics such as size and seed composition, and species response to several environmental factors as temperature, light and germination depth can influence the difference of susceptibility to herbicides applied in the soil considering different speed and percentage of germination among species (Chauhan \& Johnson, 2009).

Poor Amaranthus control under field conditions could be related to factors other than herbicide efficacy. For instance, the continuous use of herbicides have imposed selection on weeds, causing increased infestations of less susceptible species and/ or the increase of resistant biotypes within these species. Resistance cases of different species of Amaranthus (A. albus, A. hybrydus, A. lividus, $A$. powelli, $A$. retroflexus, $A$. rudis, and A. tuberculatus) to herbicides applied in pre-emergence such as diuron, prometryn, simazyne, as well as to herbicides applied post-emergence (Patzoldt \& Tranel, 2007; Bell et al., 2013) have been described.

It is possible to conclude that there are differences of susceptibility among species of the genre Amaranthus in relation to all herbicides evaluated. Overall, A. lividus presents the lowest sensitivity to the evaluated herbicides except for pendimethalin and prometryn. On the other hand, A. spinosus can be considered the species of highest susceptibility, although $A$. viridis is the most susceptible to prometryn. Alachlor, diuron, oxyfluorfen, pendimethalin, S-metolachlor and prometryn might provide the control of Amaranthus spp. species in selective doses to cotton, and combinations of these herbicides may also be an alternative to be addressed in further studies. Clomazone did not provide 
Table 4 - Estimated doses for 80 (C80) or 95\% control at 28 DAT of four species of Amaranthus and comparison to labeled doses prescribed for these herbicides in cotton

\begin{tabular}{|c|c|c|c|c|c|c|}
\hline \multirow{2}{*}{ Specie } & A. viridis & A. spinosus & A. hybridus & \multirow[t]{2}{*}{ A. lividus } & \multirow{2}{*}{\multicolumn{2}{|c|}{$\begin{array}{l}\text { Labeled dose } \\
\qquad\left(\mathrm{g} \mathrm{ha}^{-1}\right)^{\underline{3} /}\end{array}$}} \\
\hline & \multicolumn{3}{|c|}{ Estimated doses for $\mathrm{C}_{80}\left(\mathrm{~g} \mathrm{ha}^{-1}\right)^{1^{1 /}}$} & & & \\
\hline Alachlor & $(15)^{\frac{2 /}{\prime}}$ & $292 \quad(12)$ & $774 \quad(32)$ & $(33)$ & 2400 & $(100)$ \\
\hline Diuron & $(18)$ & $(18)$ & $221 \quad(18)$ & $(18)$ & 1200 & $(100)$ \\
\hline Oxyfluorfen & $(11)$ & $(6)$ & $37 \quad(8)$ & (16) & 480 & $(100)$ \\
\hline Pendimethalin & $(72)$ & (37) & $382 \quad(51)$ & $366 \quad(49)$ & 750 & $(100)$ \\
\hline S-metolachlor & $(29)$ & $(24)$ & $383 \quad(32)$ & $(36)$ & 1200 & $(100)$ \\
\hline Prometryn & $(32)$ & $(33)$ & $463 \quad(51)$ & $(38)$ & 900 & $(100)$ \\
\hline \multirow[t]{2}{*}{ Clomazone } & $(97)$ & $(83)$ & $>1000$ & $>1000$ & 1000 & $(100)$ \\
\hline & \multicolumn{4}{|c|}{ Estimated doses for $\mathrm{C}_{95}\left(\mathrm{~g} \mathrm{ha}^{-1}\right)^{\frac{1}{}}$} & & \\
\hline Alachlor & $(39)$ & $596 \quad(25)$ & $1154 \quad(48)$ & $(42)$ & 2400 & $(100)$ \\
\hline Diuron & $(24)$ & $(24)$ & $(24)$ & $(24)$ & 1200 & $(100)$ \\
\hline Oxyfluorfen & (13) & $(9)$ & (9) & (18) & 480 & $(100)$ \\
\hline Pendimethalin & $(>100)$ & $(58)$ & $(68)$ & (72) & 750 & $(100)$ \\
\hline S-metolachlor & $(60)$ & $(36)$ & $(46)$ & $(48)$ & 1200 & $(100)$ \\
\hline Prometryn & $(38)$ & (39) & $(67)$ & $(60)$ & 900 & $(100)$ \\
\hline Clomazone & $(>100)$ & $(>100)$ & $(>100)$ & $(>100)$ & 1000 & $(100)$ \\
\hline
\end{tabular}

${ }^{1 /} \mathrm{C}_{80}$ or $\mathrm{C}_{95}$ doses of herbicides as a function of weed species calculated by regression equation; ${ }^{2} / \%$ in relation to the labeled or recommended dose; ${ }^{3 /}$ Recommended doses of herbicide according to Rodrigues and Almeida (2005), and/or prescribed in herbicide labels for this type of soil.

efficient control of A. lividus and A. hybridus for the range of doses evaluated. Formulations of trifluralin 450 and 600 did not efficiently control Amaranthus species within the dose range in this study. The results of this research are relevant because they incorporate technical aspects into the decision-making process for herbicide and dose selection. Thus, selecting the best weed control may be improved by the proper identification of the existing species in the area. The integration of these factors will allow the development of systems to minimize damage to the crop and environmental impacts caused by herbicides without jeopardizing crop yield.

\section{LITERATURE CITED}

BATES, D. M.; WATTS, D. G. Nonlinear regression analysis and its applications. New York: John Wiley, 1988. $365 \mathrm{p}$.

BELL, M. S. et al. Multiple resistance to herbicides from four site-of-action groups in waterhemp (Amaranthus tuberculatus). Weed Sci., v. 61, n. 3, p. 460-468, 2013.

BOSTRÖM, U.; FOGELFORS, H. Response of weeds and crop yield to herbicide dose decision-support guidelines. Weed Sci., v. 50, n. 1, p. 186-195, 2002.
BURKE, I. C.; WILCUT, J. W. Weed management in cotton with CGA-362622, fluometuron, and pyrithiobac.

Weed Technol., v. 18, n. 2, p. 268-276, 2004.

CHAUHAN, B. S.; JOHNSON, D. E. Germination ecology of spiny (Amaranthus spinosus) and slender amaranth (A. viridis): troublesome weeds of direct-seeded rice.

Weed Sci., v. 57, n. 3, p. 379-385, 2009.

CRUZ, L. S. P.; TOLEDO, N. M. P. Aplicação pré-emergente de misturas de alachlor com diuron e cyanazine para controle de plantas daninhas em algodão IAC 17. Planta Daninha, v. 5, n. 2, p. 57-61, 1982.

FAST, B. J. et al. Critical timing of palmer amaranth (Amaranthus palmeri) removal in second-generation glyphosate-resistant cotton. J. Cotton Sci., v. 13, n. 1, p. 32-36, 2009.

INOUE, M. H. et al. Sorption-desorption of atrazine and diuron in soils from southern Brazil. J. Environ. Sci. Health, Part B, v. 41, n. 5, p. 605-621, 2006.

INOUE, M. H. et al. Bioavailability of diuron, imazapic and isoxaflutole in soils of contrasting textures. J. Environ. Sci. Health, Part B, v. 44, n. 8, p. 757-763, 2009.

LU, J. et al. Sorption and degradation of pesticides in nursery recycling ponds. J. Environ. Qual., v. 35, n. 5, p. 1795-1802, 2006.

Planta Daninha, Viçosa-MG, v. 33, n. 1, p. 137-146, 2015 
OLIVEIRA JR., R. S. et al. Sorption and leaching potential of herbicides on Brazilian soils. Weed Res., v. 41, n. 1, p. 97-110, 2001.

PATZOLDT, W. L.; TRANEL, P. J. Multiple ALS mutations confer herbicide resistance in waterhemp (Amaranthus tuberculatus). Weed Sci., v. 55, n. 6, p. 421-428, 2007.

RAIMONDI, M. A. et al. Atividade residual de herbicidas aplicados ao solo em relação ao controle de quatro espécies de Amaranthus. Planta Daninha, v. 28, p. 1073-1085, 2010. (Número Especial)

REGAZZI, A. J. Teste para verificar a identidade de modelos de regressão e a igualdade de parâmetros no caso de dados de delineamentos experimentais. R. Ceres, v. 46, n. 266, p. 383-409, 1999.

REGAZZI, A. J. Teste para verificar a igualdade de parâmetros e a identidade de modelos de regressão não-linear. R. Ceres, v. 50, n. 287, p. 9-26, 2003.

REGAZZI, A. J.; SILVA, C. H. O. Teste para verificar a igualdade de parâmetros e a identidade de modelos de regressão não-linear. I. Dados no delineamento inteiramente casualizado. R. Mat. Estat., v. 22, n. 3, p. 33-45, 2004.

REGAZZI, A. J.; SILVA, C. H. O. Testes para verificar a igualdade de parâmetros e a identidade de modelos de regressão não-linear em dados de experimento com delineamento em blocos casualizados. R. Ceres, v. 57, n. 3, p. 315-320, 2010.

RICHARDSON, R. J. et al. Pre-emergence herbicides followed by tryfloxisulfuron post emergence in cotton. Weed Technol., v. 21, n. 1, p. 1-6, 2007.
SAS Institute. SAS Procedures guide for computers. 6.ed. Cary: 1999. 373 p.

SHARMA, S. D.; SINGH, M. Effect of surfactant on leaching of pendimethalin in Florida Candler fine sand.

B. Environ. Contam. Toxicol., v. 78, n. 1, p. 91-94, 2007.

SOSNOSKIE, L. M. et al. Multiple resistance in palmer amaranth to glyphosate and pyrithiobac confirmed in Georgia. Weed Sci., v. 59, n. 3, p. 321-325, 2011.

STECKEL, L. E.; GWATHMEY, C. O. Glyphosate-resistant horseweed (Conyza canadensis) growth, seed production, and interference in cotton. Weed Sci., v. 57, n. 3, p. 346-350, 2009.

STECKEL, L. E. et al. Common waterhemp (Amaranthus rudis) control in corn (Zea mays) with single pre-emergence and sequential applications of residual herbicides.

Weed Technol., v. 16, n. 4, p. 755-761, 2002.

STREIBIG, J.C. Herbicide bioassay. Weed Res., v. 28, n. 6, p. 479-484, 1988.

SWEAT, J. K. et al. Herbicide efficacy on four Amaranthus species in soybean (Glycine max). Weed Technol., v. 12, n. 2, p. 315-321, 1998.

TROXLER, S. C. et al. Clomazone, fomesafen, and bromoxynil systems for bromoxynil-resistant cotton (Gossypium hirsutum). Weed Technol., v. 16, n. 4, p. 838844, 2002.

WHITAKER, J. R. et al. Residual herbicides for palmer amaranth control. J. Cotton Sci., v. 15, n. 1, p. 89-99, 2011. 